https://doi.org/10.31470/2706-7904-2020-15-132-136

\title{
КОМУНІКАТИВНІ ЗАСОБИ ПСИХОЛОГІЧНОГО СУПРОВОДУ ПРОФЕСІЙНОГО САМОЗДІЙСНЕННЯ ВИКЛАДАЧА
}

\section{Communicative Means of Psychological Support for University Lecturers' Professional Self-Fulfilment}

\author{
Olga Korniyaka \\ DSc. in Psychology, Professor \\ Kostiuk Institute of Psychology of the NAPS of Ukraine \\ olga.korniyaka@gmail.com \\ https://orcid.org/0000-0003-1471-9238
}

\begin{abstract}
The abstract presents the results revealing with performed regression analysis of the determinants of university lecturers' professional self-fulfilment. The research has shown that communicative factors are placed among the clearest predictors of achievement by university lecturers of high selffulfilment in their profession. It is found out that the most significant factor in achieving of high level professional self-fulfilment (general, internal and external) by these specialists is the «creativity in professional communications» predictor. The main directions, communicative means and forms of self-fulfilment psychological support are outlined on the result basis.
\end{abstract}

Key words: psychological support, regression analysis, communicative factors of professional selffulfilment, communicative means, communicative training, university lecturer.

\section{Вступ \\ Introduction}

Самоздійснення викладача вищої школи означає постійний «саморух» у професійній (комунікативно-креативній) діяльності і набуття цим фахівцем досвіду діалогічного, «інтелектуального» за своїм характером, спілкування. Це надбання пов'язане 3 обов'язковою педагогічною, когнітивною, науковою, соціальнокомунікативною та методичною ефективністю і компетентністю цього фахівця, а також виявом творчості в діяльності спілкування. Розвиток як постійне особистіснопрофесійне зростання та самоосвіта передбачають і психологічний супровід, що виступає ефективною технологією сприяння комунікативно-креативному самовираженню викладача у просторі професії. Набуваючи під впливом цих 
зовнішніх та внутрішніх чинників додаткових спонук до комунікативно-креативної діяльності, викладач дістає вагомі можливості для реалізації свого потенціалу, підвищення довіри до себе як до фахівця i, зрештою, для професійного самоздійснення.

Мета дослідження - встановлення за допомогою регресійного аналізу визначальних чинників професійного самоздійснення викладача вищої школи i 3'ясування на їх підставі основних напрямків, важливих комунікативних засобів i форм психологічного забезпечення цього процесу.

\section{Методи та методики дослідження}

\section{Methods and Techniques of the Research}

Крім теоретичного аналізу особливостей професійного самоздійснення викладача й якісної інтерпретації результатів емпіричного дослідження, здійснювалося статистичне опрацювання даних за допомогою регресійного аналізу 3 метою з'ясування предикторів досягнення цим фахівцем високого рівня самоздійснення у професії. Дослідження дало змогу встановити, що вирішальне значення в цьому процесі мають комунікативні чинники. Це зумовлено специфікою професійної діяльності викладача, здійснюваної у формі науково-педагогічного спілкування (Корніяка, 2019). До того найбільш вираженим чинником досягнення цим фахівцем високого рівня професійного самоздійснення (загального, внутрішньопрофесійного i зовнішньо-професійного) став показник «креативність у сфері ділового спілкування».

\section{Результати \\ Results}

На підставі результатів дослідження ми визначили основні напрямки та важливі комунікативні засоби психологічного супроводу професійного самоздійснення викладача вищої школи:

(1) поглиблення змісту власної професійної діяльності i досягнення задоволеності своєю роботою;

(2) постійний розвиток внутрішньої та зовнішньої професійної мотивації;

(3) розвиток ціннісних орієнтацій, притаманних особистості, що самоактуалізується; посилення ціннісного ставлення до обраного фаху; 
(4) досягнення творчої та креативно-комунікативної спрямованості особистості, забезпечення постійного вияву креативності у сфері професійного спілкування i життєдіяльності загалом;

(5) використання особистісно-психологічних ресурсів життєстійкості, поглиблення iї зв'язку з властивостями особистості;

(6) інтенсивний розвиток професійної компетентності й таких іiі структурних складових, як інформаційна, креативна, педагогічна та самоосвітня компетентності;

(7) удосконалення комунікативної компетентності як ключової складової професійної компетентності 3 акцентом на таких іï складових: (а) мотиваційному, когнітивному та інструментальному критеріях; (б) мовленнєвій компетентності; (в) невербальній (педагогічній) виразності мовлення викладача;

(8) розвиток контактності як вміння швидко встановлювати поглиблені й емоційно насичені контакти з іншими людьми. Психологічне сприяння професійному самоздійсненню повинне мати постійний характер і забезпечуватися на всіх етапах становлення фахівця (Korniyaka, 2020).

Як показало дослідження, важливим засобом вдосконалення чи психокорекції комунікативних чинників професійного самоздійснення викладача виступає комунікативний тренінг. Окреслимо деякі особливості його застосування на різних етапах професійного становлення цього фахівця.

Теоретико-емпіричне вивчення проблеми показало, що на етапах вибору професії, навчально-професійної підготовки та адаптації провідним є, на думку Е.Ф. Зеєра, Є.О. Клімова, В.В. Рижова, Г.М. Дубчак та ін., особистісний розвиток фахівця: відбувається становлення соціально та професійно важливих особистісних якостей. На наступних етапах професіоналізації (первинна та вторинна професіоналізація, період професійної майстерності) вже передує професійний розвиток, коли відбувається активне поповнення системи професійно важливих якостей, збагачення знань, вмінь та навичок. Стосовно викладача йдеться про розвиток комунікативних здатностей, пов'язаних 3 головною сферою його діяльності - науково-педагогічним спілкуванням.

Відтак, тренінг 3 розвитку професійно-комунікативного самоздійснення особистості цього фахівця може бути більш ефективним у періоди професійної підготовки, адаптації і навіть первинної професіоналізації, коли саме особистість виступає надзвичайно дієвим «інструментом» професійного розвитку і $є$ достатньо сприйнятливою до зовнішніх впливів, активно соціалізуючись і професіоналізуючись, збагачуючись новими вміннями та навичками, поповнюючи в діяльності спілкування арсенал комунікативних стратегій i тактик. У ці періоди фахове навчання виступатиме як навчання особистості професійним вмінням та навичкам 3 метою 
забезпечення ефективності професійної діяльності та спілкування. А корекційнорозвивальна робота матиме найвищий ефект внаслідок гнучкості, сприйнятливості та активності особистості фахівця.

Комунікативний тренінг буде корисним й у періоди вторинної професіоналізації та професійної майстерності. Адже він здійснює функцію психологічної підтримки і супроводу процесу адаптації фахівця до нових змін у просторі професії, зумовлюваних інноваційними процесами у сфері професій, трансформацією технологій та швидкоплинністю суспільно-економічних змін (Кокун, 2018). Маємо тут на увазі передусім вчасне набуття особистістю нових стратегій i тактик, за висловом І. Корнієнка (2017), «опанувальної поведінки», що є запорукою професійного самозбереження, запобігає фаховому вигоранню.

Дослідження показало, що самоздійсненню викладача в обраній професії сприяє психологічне забезпечення у таких формах: психологічне консультування, тематичні бесіди, комунікативний тренінг, соціально-психологічне тренування, наближені до реальної комунікації ділові ігри, раціоналізація професійних завдань через відповідне інформування, психорегуляційні засоби (приміром, тренування асертивної поведінки), а також заходи, спрямовані на підтримку доброго стану здоров’я і профілактику виникнення негативних особистісно-професійних явищ.

Надзвичайно важливим засобом розвитку діяльності викладача $\epsilon$ фасилітативна взаємодія, що сприяє вдосконаленню пізнавальних процесів (у тому числі комунікативному розвитку, становленню діалогічних взаємин) усіх суб'єктів педагогічного спілкування. 3 метою тренування здатності педагогів до фасилітативної взаємодії дослідниці Н.О. Михальчук і Н.О. Хупавцева (2020) пропонують впровадження у практику їх роботи спеціальних семінарів, що сприятиме емоційноціннісному зростанню, набуттю досвіду комунікативно-креативної діяльності й творчому самовираженню у просторі професії.

\section{Висновки \\ Conclusions}

Пошук нових варіантів виконання зумовлених фахом функцій, урізноманітнення сфер і форм взаємодії, індивідуальний підхід у спілкуванні, дадуть змогу успішно розв’язувати проблемні ситуації педагогічного процесу; істотно поповнити комунікативні стратегії та техніки міжособистісної взаємодії, підтримувати вербальну та невербальну активність; підвищувати самоконтроль i психологічний вплив на партнера зі спілкування; посилювати особистісну мотивацію, спрямовану на досягнення мети діяльності. А розвиток креативності у сфері ділового 
Psycholinguistics in a Modern World - 2020. Proceedings of the 15th International Scientific and Practical Conference (Pereiaslav-Khmelnytskyi, 22-23 October, 2020)

спілкування може не тільки сприяти професійному самоздійсненню викладача, а й виступати профілактичним засобом запобігання професійним деформаціям.

\section{Література}

References

Кокун, О.М. (Ред.). (2018). Психофізіологічне забезпечення професійного самоздійснення фахівия в умовах сочіально-економічних перетворень. (Монографія). Київ. http://lib.iitta.gov.ua/id/eprint/712848

Korniyaka O.M. (2020). Psychological support for university lecturers' communicative and professional self-fulfilment. Scientific achievements of modern society. Abstracts of IX International Scientific and Practical Conference (Liverpool, April 28-30, 2020), (pp. 147 - 156). United Kingdom: Cognum Publishing House. https://sci-conf.com.ua/topics@ sci-conf.com.ua

Корніяка, О.М., Петренко I.В., \& Гомонюк, В.О. (2019). Спілкування у професії викладача// Людина та сочіум: сучасні проблеми взаємодії (психологічні та педагогічні аспекти): матеріали Міжнародної наук.-практ. конф. (м. Львів, 27-28 вересня 2019 р.), (с.45-48). Львів. 